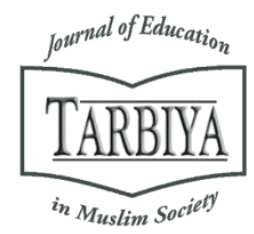

Available online at TARBIYA: Journal of Education in Muslim Society Website:

http://journal.uinjkt.ac.id/index.php/tarbiya

TARBIYA: Journal of Education in Muslim Society, 5(2), 2018, 193-211

\title{
ICT-BASED TEACHING OF ENGLISH AT MADRASAH ALIYAH IN KALIMANTAN
}

\author{
Umar Fauzan, Luluk Humairo Pimada \\ Institut Agama Islam Negeri Samarinda, Indonesia \\ E-mail: umar.fauzan@iain-samarinda.ac.id
}

Received: $10^{\text {th }}$ September 2018; Revised: $27^{\text {th }}$ November 2018; Accepted: $28^{\text {th }}$ December 2018

\section{Abstract}

Some teachers use ICT as a medium for teaching by using slide presentations. Many others use Information and communication technology (ICT) as a teaching media to develop the students' independent learning. The purpose of this research is to reveal: what ICT applied in teaching English in Kalimantan, how to apply ICT in teaching English in Kalimantan, and what barriers factor in developing language skills through ICT utilization in Kalimantan. This is a qualitative descriptive study that attempts to describe the use of ICT in English teaching in Kalimantan. The subjects of this study are English teachers in three provinces in Kalimantan; East Kalimantan, South Kalimantan, and North Kalimantan. Some instruments were used, including: interviews, observation, and documentation. Miles and Hubberman models are used for data analysis. The results show that: first, the English teachers use ICT in English classes in Kalimantan although it is very limited, since they are only familiar to use multimedia. Meanwhile, E-Media, E-Learning, E-Library, and Web-based Communities are rarely used. Secondly, the teachers of madrasah Aliyah in English teaching in Kalimantan more often use LCD projector by using a song or film in the laptop. Third, some obstacles in the application of ICT in teaching English are the ICT equipment problem, limited internet access, lack of the utilization of applications in cellphones, and age constraints.

Keywords: ICT; English language teaching; e-learning

\section{Abstrak}

Beberapa guru menggunakan Teknologi informasi dan komunikasi (TIK)sebagai media untuk mengajar dengan menggunakan slide presentasi. Banyak orang lain menggunakan TIK sebagai media pengajaran untuk mengembangkan pembelajaran mandiri siswa. Tujuan dari penelitian ini adalah untuk mengungkapkan: apa TIK yang diterapkan dalam pengajaran bahasa Inggris di Kalimantan, bagaimana menerapkan TIK dalam mengajar bahasa Inggris di Kalimantan, dan apa faktor penghambat dalam mengembangkan keterampilan bahasa melalui pemanfaatan TIK di Kalimantan. Ini adalah studi deskriptif kualitatif yang mencoba menggambarkan penggunaan TIK dalam pengajaran bahasa Inggris di Kalimantan. Subjek penelitian ini adalah guru bahasa Inggris di tiga provinsi di Kalimantan; Kalimantan Timur, Kalimantan Selatan, dan Kalimantan Utara. Beberapa instrumen digunakan, termasuk: wawancara, observasi, dan dokumentasi. Model Miles dan Hubberman digunakan untuk analisis data. Hasilnya menunjukkan bahwa: pertama, guru bahasa Inggris menggunakan TIK di kelas bahasa Inggris di Kalimantan meskipun sangat terbatas, karena mereka hanya terbiasa menggunakan multimedia. Sementara itu, E-Media, E-Learning, E-Library, dan Komunitas berbasis web jarang digunakan. Kedua, para guru madrasah Aliyah dalam pengajaran bahasa Inggris di Kalimantan lebih sering menggunakan proyektor LCD dengan menggunakan lagu atau film di laptop. Ketiga, beberapa kendala dalam penerapan TIK dalam pengajaran bahasa Inggris adalah masalah peralatan TIK, akses internet yang terbatas, kurangnya pemanfaatan aplikasi dalam ponsel, dan batasan usia.

Kata kunci: TIK; Pengajaran bahasa Inggris; e-learning

How to Cite : Fauzan, U., Pimada, L. H. (2018). ICT-Based Teaching of English at Madrasah Aliyah in Kalimantan. TARBIYA: Journal of Education in Muslim Society, 5(2), 193-211. doi:10.15408/tjems.v5i2.10414.

Permalink/DOI: http://dx.doi.org/10.15408/tjems.v5i2.10414 


\section{Introduction}

In this technological era, people connect and communicate through the technology. Almost everyone uses cellphones and internet in everyday life. Many of them get used to work with computers and laptop connected to internet. Education changes and develops following the development of the society in every era. When technology and information become a part of life for every people, then it also enters the education world. Information and communication technology (ICT) becomes an integral part of the educational process lately. Khaloufi \& Laabidi (2017) found that it is apparent that computer technology has become an important part of our daily lives.

The use of information and communication technology in teaching and learning in the schools is increasingly being applied and is starting to become important. The teachers and the students get used to the life of information and communication technology and they make the classroom interaction come into contact with the ICTs. The use of ICT is needed in the context of effectiveness (Husain, 2014; Iman, 2015; Suhirman., 2015) and efficiency of learning (Kurahman, 2013; Mustofa, 2016). Instead of those studies, Dawes (2001) also confirms that technologies have the capacity to assist education across the curriculum and supply chances for useful communication between learners and educators in ways that have not been possible before. A lot of studies have revealed that the implementation of ICT in classrooms have come up with many fruitful consequences for both teachers and learners as well. It has increased their willingness to develop their knowledge through these modern tools (Laabidi, 2017b). Another study is conducted by Khaloufi \& Laabidi (2017) who examine that teachers, in this technological information age, should know both the subject matter they instruct and the different effective ways this subject matter may be changed using computer technologies, that is the high demanded of skilled teachers to master technologies could not be avoided as the main requirement in this globalized era.

In the context of teaching and learning, information and communication technology has developed rapidly with several ways of using it. The teachers use ICT to prepare lesson plan by browsing and adjusting teaching planning, to find courses and teaching materials, to get ideas and innovative teaching strategies, to collect books and teaching sources and references, and to finalize teaching evaluation. They use ICT as a learning presentation media by using $\mathrm{Ms}$ Powerpoint presentation slide. Some of the teachers instruct their students to submit the assignment using email. They also use it as a medium of self-learning or e-learning, such as: giving their students tasks of readings or searching for resources from internet, findings some teaching materials, and making online discussion with their students.

To maximize the use of ICT, the teachers need to start seeing ICT as a better tool to enhance its pedagogic practices (Kennah, 2016) and to know the roles and the effect of the ICTs (Sudibyo, 2011). It is harmonious with other opinion conveyed by Abu-Rmaileh \& Hamdan (2006) who stated that integrating computers, smart phones and other instruments in education can reform classical strategies of teaching, motivate learners to be more autonomous and self-reliant, and boost students' achievements and teachers' performance In fact, in the newest curriculum in Indonesia, it is mentioned that the technology should be integrated in teaching and learning process to improve the efficiency and effectiveness of teaching and learning process. Particularly, Indonesia have to prepare all the integrated curriculum to face the worldwide integration or 
globalization known as Industry era (Nova, 2017).

The advantage of information and communication technology is the unlimited sources for learning and it can be done anytime and anywhere. The teacher gives the assignment in the school and the students can do it at school, at home, in the library, or in the public places. The teacher can use email, e-books, elibrary, online discussion, mailing list, news groups, and others as a source of making and distributing the assignments to the students. The students are stimulated to explore and find the answers independently without having to be in the classroom.

ICT is useful to support the implementation of teaching and learning of English. The era is different. The previous English teaching methodology might not be fit with the digital people and out-of-date for those who are living in the rapid exchange information era. The English teacher can teach students to listen (Rathnasena, et al, 2013), reading (Roig-Vila \& Mengual-Andrés, 2014), writing (Annamalai, 2017; Styati, 2016), or speaking (Rathnasena, et al., 2013). Through ICT, the learning system shifted from focusing on teaching to focusing on learning. It is oriented to achieve goals in order to prepare students to become the independent learners. In agreement with numerous studies have indicated that there is a strong positive correlation between students' achievements and the use of ICT in the classroom. According to Matusevich (1995), technology has restructured the whole process of learning and teaching in the sense that it has helped students to reshape their learning strategies. Bull (2005) stated that computer technology integration could help learners develop their thinking skills and creative abilities in the sense that they have access to more technological tools outside of educational institutions than inside schools.
English teacher and English learners need knowledge to gain those magnificent benefits from the use of information and communication technology. The knowledge should incorporate how to install and remove several significant software programs. In other words, the teacher and the students are required to master the necessary skills to operate different software tools especially word processors, Internet browsers, spreadsheets, and email (Mishra \& Koehler, 2006). The teacher needs to master technology to transfer knowledge, to create positive teaching atmosphere, and to succeed his/her English teaching. The students need to understand technology to make English learning easier and to master English. Cahyani \& Cahyono (2012) revealed that technology, as language teachers believe, is inseparable with the success of teaching and learning activities.

Regardless of the types of the technology, either non web-based or web-based, they facilitate language learning. Almaktary \& AlKadi (2017) mention language learning today is boundless to neither classroom nor textbooks. Technology enables the learner nowadays to learn on their own more than what they learn in classroom to create learner autonomy. By way of explanation, it is self-evident that ICT has been developing very quickly in recent years and opens new directions in the area of education. In other words, the speedy growth in ICT has brought conspicuous and notable changes in the twenty-first century, and influenced the requirements of modern societies. Due to the significance of ICT in society and possibly in the future of education, recognizing the likely barriers to the integration of these technologies in schools would be a valuable step in ameliorating the quality of teaching and learning (Laabidi \& Laabidi, 2016). 


\section{Relevant Studies}

Pulungan (2017) found that the utilization of information communication and technology in Islamic education learning, that is, by using learning materials and PowerPoint media digital. Making of learning media of Islamic education with the topic aspects of ethics and morals using PowerPoint is designed based on lesson plan of learning Islamic education used to students with attention to the value of competency standards. The design of digital learning materials using the application of SOM (Screen Cast Omatic) that is very interactive. The learning aspect of ethics and the morals of using PowerPoint and digital learning materials provide a positive impact on the learning motivation of students. A similar study conducted by Mansor et al. (2017) who found that the shift of era also led to changes in the educational system, from the 'chalk and talk', to technology-assisted teaching, the use of overhead projectors, OHP, media and so forth. Meanwhile, another study conducted by Davidson (1989) who observed that the kind of teachers' computer utilizations is dependent on both their knowledge and attitudes towards implementing these technologies in their instruction.

Rahim (2011) also found that technological innovation can be supported to provide significantly better access to education, information and knowledge in UIN Alauddin Makassar, as well as the wider community can access web UIN Alauddin Makassar so get information about academic services, financial administration and the learning process. It is also supported by other researcher who stated that if nations intend "to meet the challenges of the information age, then educators will have to realize their responsibility to utilize the existing and emerging technologies" (Finley, 2003). In other words, it can be implied that most of teachers are required or suggested to improve adequate and effective training so they are capable of getting successful use of computer technologies in classroom teaching learning process.

Those previous studies revealed that ICT is implemented in the teaching and learning, e.g.: Islamic education, the students' need to use ICT and the teachers should know about implementing ICT, because ICT provides better access to education, and using ICT meets the challenges of the information age.

There are similarity and differences this research and the previous researches. The similarity among the previous studies and this study is same research about the use of ICT. The differences are in the subject of the lesson which is language research, the kinds of ICT explored in this research, and the issue of barrier of using ICT in Kalimantan. The researchers haven't found any research about the implementation of ICT in the context of teaching and learning of English and Arabic in Kalimantan. So that, it is the reason why this study was conducted.

\section{Method}

This is a descriptive qualitative study that tried to describe the use of ICT in English language teaching in Kalimantan. The subject of this research was the English teachers from 3 provinces in Kalimantan; East Kalimantan, South Kalimantan, and North Kalimantan.

Researchers brought several instruments in this research. The instruments included: interview, documentation, and observations. Interview is a kind of instrument implemented by giving questions to the teachers and headmaster. Observation is an instrument applied by entering the language learning classroom. The documentation is a model of instrument done by gathering and analyzing all the documentation that is owned by the school with regard to the application of ICT in schools. The documents included: certificates, modules, 
guidebook, the charter Award, lesson plan and others.

Interview was conducted by visiting schools to do interviews with teachers and the headmaster. The researcher went to MAN 1 Banjarmasin, MAN 2 Banjarmasin, and MAN 3 Banjarmasin on $11^{\text {th }}-19^{\text {th }}$ April 2018 to gain the data about the use of ICT there. In Banjarmasin, the researcher interviewed the English teachers and headmaster, observed the language teaching and learning, and checked the documented related to the use of ICT in those schools. In Samarinda East Kalimantan, the researcher went to schools to get data about the use of ICT at MAN 1 Samarinda and MAN 2 Samarinda on $21^{\text {st }}-25^{\text {th }}$ April 2018 by addressing some questions to the English teachers and headmaster in the form of interview, observing the English classroom, and getting related documentation. On $4^{\text {th }}-6^{\text {th }}$ May 2018, the researcher collected the data from MAN Bulungan North Kalimantan by interviewing the teachers and headmaster, observing the classroom learning process, and getting the data from documentation related to the use of ICT.

The research digged up about "The Development of Language Skills through the use of ICT in Kalimantan" was done by systematically step that aimed to answer the formulation of problems and achieve goals to be achieved in this research. The research was done to get information about the development of language skills through the use of ICT in Kalimantan that specifically for: 1) ICT in English language learning Media, 2) How the application of ICT in language learning, 3) the development of language skills through the use of ICT in Kalimantan. As reported by Hicham (2017b), many researchers have proposed that technology could not be integrated in teaching unless professors possess positive attitudes towards the new technological instruments. Rogers (2000) pointed out that attitudes regarding computers play a considerable part in the process of ICT implementation since these attitudes might become a big obstacle hindering the successful and effective use of computer technologies in the classrooms.

Data were analyzed using model Miles \& Huberman (1994) which consists of three strands of activities that occur simultaneously, that are the reduction of the data, the presentation of data, withdrawals/verification conclusion. Data validated by using data triangulation techniques. The researchers used multiple researchers' triangulation and methods triangulation. The data triangulation technique was done to make sure the collected and analyzed data valid and trustable.

\section{Results and Discussion}

\section{ICT media in English language teaching in Madrasah Aliyah}

This research was carried out to find out what ICT media used in English language learning in Madrasah Aliyah in Kalimantan. The research involved respondents from English teachers and headmaster of Madrasah Aliyah in South Kalimantan, North Kalimantan, and East Kalimantan. The results of the interviews with the teachers of English in Madrasah Aliyah level regarding to ICT Media in the English teaching in Madrasah Aliyah in Kalimantan generally shows the teachers use information and communication technology in his/her teaching.

Teacher A answered to the questions about using a computer and LCD Projector for presentation while teaching English language as follows:

"If there's any content that needs to be shown by using LCD, I use the LCD. If it is sufficiently described, I just explain it. The laptop is used to create the question, type the question. I use a laptop. The computer 
is used by my staff do school report, lesson plan and others"

When he was asked whether he used cellphone connected to the speakers in teaching English, especially while teaching listening, teacher A replied.

"Never. Cell-phone is used to phone or send messages. If the listening lesson using the English Language Lab, although not all of them work. "

Regarding to the use of cell-phone in English classes, teacher D answered many students use cell-phone for practice and answer the question, including assignments in the form of the application Edmodo. The students answered the question that distributed by cellphone. So, the system is already paperless, it means without the use of paper again, the school applies the concept of go green. He argued that Edmodo make English teaching and learning fun and effective. As reported by Puspitaloka et al (2018) who examined that Edmodo is easily installed on Computers, Notebooks and Android. It is the social media network which collaborates and connect, share content and get access homework, school notices and grades.

Then, teacher A answered related to question whether the use of English laboratory in teaching English by stating:

"The school has lab, but not all of the headphone can be used. Sometimes we learnt in the English LAB. However, some tools are broken. Not all students can use."

Similar answers delivered by teacher B and D who stated that technology such as LCD Projector with computers for the presentation of the subject matter especially in the high class and or use of the English LAB to support teaching and English language learning process. Even so, some teachers also expressed their thought about the constraints of the teaching and learning infrastructure, especially in the English LAB. It was always many problems.

When teacher A asked, whether using the website, for example, for browsing, blogging, email in the English learning, teacher A answered:

"Never use e-mail nor blog. The students were instructed to do googling some books or any sources to search examples of English language materials, such as reading that suits to the material. Also looking for text which matches the curriculum"

When researcher asked teacher $\mathrm{A}$ whether using youtube in the English learning, this is the answer of teacher A:

"Ever, but rarely. Internet access is always off, often slow. If the students often access internet, I worried they will open negative content in the internet. It is difficult to monitor, because I must monitor many students in the class. If the students often access the internet, I am afraid they will access negative content"

Interesting answer about the use of the website is given by teacher B which stated that in the internet era now, all teachers can use all of the existing content on the internet for English languages learning. It relates to the reality that nowadays, second and foreign language teachers have the options to use technology in the classroom. Therefore, technology is indicated as one of factors in the 21 st century education. As a result, teaching and learning approaches have changed to suit the digital age by adopting technology or incorporating e-learning into classrooms (Cowie \& Sakui, 2013).

To find the necessity material needs in teaching the English skills in the English language, including: listening, reading, writing, and speaking can browse and get a wide range of 
learning material, particularly listening, watching or downloading from youtube. The English can also use Edmodo to conduct e-learning. The teachers could send email to students using features that are on Edmodo. This is in support of Cauley (2013) from "A guide to Explain it all" (IT Babble.com) in Monalisa and Ardi, (2013) who declared that one of the educational websites that takes the ideas of social network and makes it appropriate for a classroom is Edmodo. Edmodo helps students and teachers to connect one and another by sharing ideas, problem, and useful tips.

Related to the topic stated above about the use of e-Learning (for example: Edmodo, web course) in the learning. Teacher A and teacher D replied:

"It never was. The internet is used to search for material in accordance with the taught course"

Different answers given by teacher $\mathrm{D}$ it is accustomed to using e-learning in English language learning who stated:

"I used to use Edmodo. Edmodo can be used to teach all English skills. In writing can be used in the preparation material and the commission. If Speaking lesson, the way to use it is by providing the recorded material first, after that it is given to the students as teaching material, as well as the record for his/her practice. For Listening, I created the material and developed questions as learning test which could be multiple choice or essay. After that instruct the students access Edmodo, and guide them learn online exercises and then ask the students answer the questions. Teaching reading is done by making the reading material and then develop a reading practice, as well as the assignment of which can be uploaded to Edmodo."
This is in line with Purnawan et al. (2016) who assumed that Edmodo also could be used in teaching writing in a blended learning setting since it facilitates students' engagement cognitively. The teachers use Edmodo as an online blackboard and inbox to post polls, quizzes, and assignment guidelines and invite student to submit finished assignment (Evenddy, 2016). It is also in line with Puspitaloka et al (2018) who examined that for the students, using Edmodo can collaborate their project, asking questions and working together.

Teacher D added:

"The ease of Edmodo is can be done at any time and anywhere. It does not need any specific time and place. If the teacher has free time, he/she can use to create, prepare and upload materials using Edmodo."

Bergmann and Sams in Basal (2015, p.2) argue that: a flipped classroom can be described as a setting where that "which is traditionally done in class is now done at home, and that which is traditionally done as homework is now completed in class". Using flipped classroom technique, the students will get the material before they come to the class and it needs a modern media which utilize educational social network. It called Edmodo. Edmodo is an application that designed in education system.

In addition, teacher added:

"Not many teachers use edmodo. Some teachers use edmodo, but it is not full used. They only operate it in a simple way. Some teachers also try and use other e-learning applications, such as moodle, Quipper school, Google Classroom.“

This is supported by Hourdequin (2014), who found that Edmodo is described as a free online learning management system that offers a secure virtual space for students and teachers to 
share and discuss texts, images, audio files, and videos. Thus, Edmodo could be accessed through web browser or smartphone application (iOS and Android). The teachers could create communities or classes for specific groups of students on Edmodo. When a teacher creates an Edmodo group, he or she receives a group code that could be used by students. Besides, not only teachers and students but also parents are able to have a code of their own. It is aimed to allow them to check, support, and work together with their children (Batsila, et al., 2014).

Next question is about downloading school's electronics book. The answers from teacher $\mathrm{A}$, teacher of $\mathrm{D}$, and $\mathrm{E}$ are:

"I’ve ever downloaded electronic books. The book from education department for learning materials, or download the electronic school books for specific lessons. I've never downloaded a book from the digital library of the Government or University. "

In terms of downloading textbooks, teacher D explained that electronic textbooks are available in the website of kemendikbud, the teacher can access the website which provides learning materials for English language from blogs or other sites. The most interesting of course is Edmodo. Teachers can upload books or prepare material, exercises, or questions. For books, a teacher might download or help other friends get the e-book any time she/he wants to, just get the link to download. This is similar to the study by Looi \& Yusop (2011) who provide some benefits of using Edmodo in the teaching and learning process. First, the students could post any comments regarding to the assignments. Second, students are able to get reward badges that could increase their learning motivation.
Then, teacher A was asked about sharing the English teaching through cyberspace discussion forums, responded by teachers A:

"Here, teacher didn't join any forum in the internet. As I know, they join whatApps group only."

The researcher also asked about the WhatsApp group discussion of teaching English language. The answer from teacher $\mathrm{A}$ is:

"Rarely, we discuss lessons in WhatsApp. Nothing to discuss, mostly discussion about the latest news. Sharing information, that's all"

Related to the questions about WhatsApp group or cyberspace discussion forums, guru D responded:

"Only information. Whatsapp is used only for exchanging information, for example about the schedule or general information about the English language teaching. Discussion of the lessons can be done through Edmodo. "

With regard to questions concerning the constraints in the use of ICT, all of the respondents answered that the barriers are about internet access. In the school of teacher B, teacher $\mathrm{C}$, teacher $\mathrm{E}$, teacher $\mathrm{F}$, there is no problem from the aspects of the equipment in the laboratory. Meanwhile, teacher D stated that the language laboratory should support English teaching and learning where the school did not provide it. That is why, computer laboratory becomes the solution. Raman \& Mohamed (2013) conducted a similar study in investigating the issues in integrating ICT in teaching English in Malaysian secondary school. He found several issues in technology integration in Malaysia, including lack of access to technology, lack of time, lack of technical support, lack of professional development on how to integrate 
technology, lack of school funding, and lack of support from administrators.

In terms of the constraints of the use of ICT in English language teaching and learning, according to the results of the interviews with the teachers of Madrasah Aliyah, one of solutions proposed by teacher $\mathrm{D}$, that is, to incorporate all of the menus and facilities in edmodo. At any time, if teacher had time to open cellphone or laptop, he could deliver English teaching. Another solution was given by another teacher was to complete the infrastructure for the use of ICT. If a teacher faced a difficult problem related to the use of ICT which could not be handled, the solution was communication to the school principal. A teacher also needed to be creative solving problems by using material teaching variations and implementing different teaching methods to motivate the students.

The results of the observation in the English language learning classroom on September $17^{\text {th }}-$ $19^{\text {th }}$ April 2018 in Banjarmasin, on $24^{\text {th }}$ April 2018 madrasah aliyah at Samarinda, and May $5^{\text {th }}, 2018$ in Bulungan shows that aliyah madrassah teachers do not always operate or use ICT. The most frequently used were the LCD projector with a laptop using application power point presentation to convey the material. Madrasah Aliyah teachers also used computers to play the movie or song in listening or speaking class. It seems that they seldom operate ICT. In fact, this finding is similar Addison (2011) who notes that small-sized screen is one of barriers in implementing Edmodo as an educational social network.

This study reveals that teachers, although not many, have started to use ICT in English language learning includes: 1) LCD projector and English Laboratory are the most frequently used Multimedia, 2) using email and youtube or other sites that provide English language learning material as well as using Edmodo in English language learning to upload and develop teaching material, 3) using E-Library to get a book or teaching materials, and 4) Web-based Communities was not widely used by teachers. ICT is possible and effective instrument for presenting educational opportunities. Many teachers employ ICT in their classes to boost their students' motivation. This is in line with Trimmel and Bachman, (2004) who examined the effect of presenting laptops into classrooms and one of their findings was that: "Information technology has a positive impact on school attendance and learning interest”.

Not all teachers use online learning with consideration of the abuse of the internet to the negative things like accessing a negative content that is not worthy to be opened. It is supported by the study of Cox et al., (1988) and Kumar \& Kumar (2003) who assume that lack of training is a potential source for educators' low levels of confidence and negative attitudes towards computers. To the degree that other study conducted by Poole \& Jackson (1993) who supposed that the possession of less computer experience or negative attitudes toward the use of ICT is expected to result in teachers' reluctance to integrate these new technologies in their teaching practices.

From the results of interviews, observations, and documentation about what media used by madrasah aliyah in English language learning shows the English teachers use ICT in English classes in Kalimantan although it is very limited, since they are only familiar to use multimedia. Meanwhile, e-media, e-learning, e-library, and web-based communities are rarely used.

\section{The application of ICT in the teaching English language in Madrasah Aliyah}

There are several aspects of ICT can be used to support English language learning in schools, namely multimedia, e-media, e-learning, or elibrary. 
English language teachers of madrasah aliyah in Kalimantan implement the English language learning through the stages of preparation beforehand by setting up teaching device includes lesson plan, evaluation of teaching, as well as the media that will be used. In terms of the use of media, English language teachers madrasah aliyah in Kalimantan is already acquainted with ICT such as multimedia, e-media, e-library, e-learning. ICT what is to be used is determined based on the availability of facilities and infrastructure considerations, conformance with the curriculum, as well as aspects of the effectiveness and expediency of. It also in consonant with numerous studies have found that computer experience reduces the fear of utilizing ICT for teaching goals (Dyck \& Smither, 1994; Lee, 1997).

ICT might be implemented by the English teachers in various ways. The use of LCD projector with a computer or gadget, the use of the computer independently to the making of matter, or interactive computer use are the ways in using multimedia. The use of e-mail, youtube, blog, or webpage or general learning are the ways in using e-media. E-Learning can be used by applied some interactive application, such as Edmodo, moodle, web usage course, google's classroom, or other applications that are designed for such learning quipper and others. E-Library or digital library is provided by the government, the example here is the Perpusnas. Several colleges develop a digilib or library. The virtual world learning sources provided by institutions or personal blog or provider-shaped links to eBooks. The last is a web-based virtual world community, such as the forum or the mailing list.

It is similar to the study conducted by Barker (1994) who found that institutions, teachers, students adn community are required to develop sufficient knowledge about technologies such as computers, the Internet and digital videos. This is because there has been a shift from a focus on information transmission through books and chalk to a concentration on information processing via computers and the internet. Meanwhile it also supports Potosky \& Bobko (1998) who assumed that individuals' experience with computers can be measured based on some important criteria such as ownership of a computer, type of computer training, years of use and the frequency of utilizing computer technology.

Observation results showed that teachers of madrasah aliyah in English language teaching in Kalimantan are more often using multimedia LCD projector with usage-shaped computer that is more dominant, while in online learning it is rarely used. LCD projectors are used to deliver content, where the occasional is added with songs or pieces of short films for teaching listening or speaking. It is pursuant to Parkisnon \& Hollamby, (2003); Roweliffe, (2003) who discovered that PowerPoint motivates students, if it is exploited adequately. Obviously, ICT like videos, television and multimedia computer software can be employed to supply real content that will attract and involve the learners in the learning process.

E-mail, youtube, blog or webpage is rarely used. Generally, English language teachers of madrasah aliyah in Kalimantan use e-media though not many do. This is because many of the more frequent use of media or multimedia from e-media in English language learning. Several madrasah aliyah in Kalimantan have not been complemented by adequate infrastructures, including no access or internet hotspot for the teacher and his students, so the students cannot use e-media. This is in contrary with the submission of Anas \& Musdariah, (2018) posit that being a professional teacher, they should master six perennial asepct of e-teacher development, those are teacher technology 
competency, professional use of ICT, professional use of internet, web-based technology skills, ESL teacher's digital, and ESL materials and resources development.

E-library has not been widely used by English language teachers in Kalimantan where they are maximizing the printed textbook suggested by school principle and most additional reference textbook by downloading the electronic school books provided by the Ministry of education and culture. Some other teachers took the material and materials from the internet in accordance with existing teaching material in the curriculum. Very little, there are also teachers who took the eBooks from the websites of the provider of eBooks.

There is a teacher at madrasah aliyah at Banjarmasin who practices E-Learning in English language learning using Edmodo. The results of observation and interviews showed that the teacher is so accustomed to using Edmodo and rely on English language learning. The teachers felt comfortable using Edmodo since learning material, material preparation exercises, assignments and questions can be done from anywhere and anytime. English language teaching includes practice and tasks doesn't have to be done in the class but could be from anywhere, including when school is holiday or when relaxing at home with family. All of material of English teaching can be prepared offline, including recorded material for listening and speaking. When it was done, the materials can be uploaded to Edmodo. Thus, the students who open cellphone able to learn English from anywhere anytime. This finding supports other studies conducted by AlKathiri (2015) and Enriquez (2014) who highlighted that using Edmodo in education could raise some challenges, first challenge is low internet speed and internet connection problems, second challenge of using Edmodo as an educational social network is the small-sized screen of the phones which makes it difficult for students to view all the course materials on the phone. Some students may not always access Edmodo from their laptop. It is also supported by Addison (2011) who notes that small-sized screen is one of barriers in implementing Edmodo as an educational social network. This is in contrary with the submission of Insani et.al (2018) posits that undergraduate students showed positive response and attitude towards the use of Edmodo in their learning process. In other words, instead of bringing some obstacles, using Edmodo also bears some progressive, productive, useful activities and perspective in learning process.

\section{Barrier factor of English language learning through ICT}

Observations and interviews result in madrasah aliyah in Kalimantan also showed the presence of obstacles in the implementation of ICT.

The first obstacle is that computer equipment is still limited in madrasah aliyah. The computer was usually used for the technology subject and was not used in the English language teaching. Not many, there is also madrasah aliyah equipped with computers for English language learning. Other obstacle is some teachers were not familiar with technology and they tended to used conventional media. Lacking knowledge of technology can be serious problem for teachers who must teach the students in this technological era. This is similar to the study by Ertmer, (1999) the first-order obstacles which are extrinsic to professors may incorporate lack of infrastructure, insufficient time, inadequate training, and lack of technical assistance. It relates to a similar study conducted by $\mathrm{Hu}$ and McGrath (2012) in integrating ICT into college who erected several obstacles in implementing technology integration and carried out that insufficient ICT facilities, 
teachers'limited ICT skills and pedagogic expertise, lack of effective communication networks, and inadequate technical support and ICT-related training hindered the ICT implementation in China. Meanwhile, Raman \& Mohamed (2013) also conducted a comparable study in exploring the issues in integrating ICT in teaching English Malaysian secondary school and initiated several issues in technology in Malaysia, including lack of access to technology, lack of time, lack of technical support, lack of professional development on how to integrate technology, lack of school funding, and lack of support from administrators.

The second obstacle is access to the internet. This is the main problem in almost all schools. The presence of the teacher wishes to use online media is not yet supported by the existence of adequate internet access. Some schools have been equipped with internet access also have not adequately because when many are using internet access simultaneously, then access becomes slower. Laabidi \& Laabidi (2016) found that Moroccan university English language teachers face multiple barriers such as large classes, lack of computers, lack of Internet and insufficient technical support that prevent them from using ICT in their teaching practices. These findings supported by Chouit, et.al (2017), they found that the barriers that limited professors' use of computer technology for pedagogical objectives were lack of basis infrastructure, lack of equipment and materials, lack of teachers' computer skills, and lack of appropriate computer training, lack of time, and lack of administrative support.

The third obstacle, not all madrasah aliyah has a language laboratory. Almost all of the madrasah aliyah already has a computer laboratory, but not many have a language laboratory. The teachers used computer lab to teach English instead of using English language lab. So it's no wonder, learning becomes not perfect due to the setting of the room for a computer lab setting is different to the setting of language lab. In the computer lab, each table will be equipped a single unit of a computer to type, while the language lab at each table should also be coupled with separate facilities for listening to headphones listening material is rotated or controlled by a set of electronic form of computer/dvd driver and master system that could be operated by English language teachers to teach English language. Then this finding harmonious with the study conducted by Tanveer (2011) who investigated the perceptions from both EFL students and teachers in Oman found that the major challenges in integrating technology in classroom are less technology support, lack of confidence, lack of experience of teachers and students with technology, limitation of time in preparing their instructions for electronic transmission of knowledge, and lack of e-learning resources. This result is also in agreement with the study conducted by Laabidi $\&$ Hicham (2016) who found that those obstacle factors were: professional development, access to technology, technical support, and functionality of the technology. Obviously, if ICT resources cannot be accessed by the instructor, then it will not be utilized.

The fourth obstacle is no application utilization in the gadget. One of gadget that almost all teachers and the students have is cellphone. Cellphone's application has not been underutilized. Although the cellphone application possible for use in teaching English, for example language teaching with play podcasts and attached to the speaker, but this way is still not known by many of the teacher. Though not denying if there is a teacher at madrasah aliyah Banjarmasin relied on cellphone in the English language learning through application edmodo. Therefore, teachers who have little or no confidence in applying technologies in their occupation will attempt to escape them 
altogether (Dawes, 2001b; Larner \& Timberlake L, 1995; Russell, Bradley,1997; Jones, 2004). Lack of effective training is another obstacle against the use of ICT into teaching. Brand (1998) has asserted, "If students are going to be prepared for a technological society, they must be taught by confident and skilled teachers. As the result, these hindrances can only be reduced by adequate training and development of teachers". In other words, all those goals depend on skilled teachers and the motivated students.

The fifth barrier is age. It cannot be denied this is one obstacle that arises regarding the application of ICT. There are not many teachers who are sufficiently literate to use encryption technology modern technology all good online and offline English language learning classes. According to Kay (1990), age is regarded as one the most influential predictors of attitudes towards computers. Similar to the gender factor, studies showed mixed results. Jay \& Willis (1986) found that younger people tend to possess more positive attitudes than older ones. Also, Nickell \& Pinto (1987) mentioned that there is a negative correlation between age and computer attitudes. These facts related to some opinions that the lack of effective training is another obstacle against the use of ICT into teaching. Brand (1998) has asserted, "If students are going to be prepared for a technological society, they must be taught by confident and skilled teachers. All these aims can only be done by adequate training and development of teachers". Lack of technical support is another factor that stops schools from successfully delivering excellent and imaginative lessons using ICT. Jones (2004) declares that the breakdown of a computer generates disturbance and if there is lack of technical support, then it is possible that the typical repairs of the computer will not be implemented resulting in teachers not employing computers in teaching.
The sixth is the constraint accuracy to choose ICT applications. Not many teachers enable to use Edmodo. Some teachers who are using Edmodo have not fully understood how to operate Edmodo. Many teachers who use the elearning application, such as Moodle, Quipper school, Google classroom, are not fully wellusers. Teachers are advised to use Edmodo, because it's easier, simple, and has many features that can be used in learning. It is in line with Becta (2004) who categorizes the barriers as falling into two primary kinds: the teacher level barriers such as lack of time, lack of confidence and resistance to change, or the school-level barriers such as lack of training and access to resources.

Moral consideration and benefit the internet is becoming a troubling obstacle for most English language teachers. The results of the interviews in the field show there are English language teachers madrasah aliyah who consider that technology brings negative things. It is also similar to some studies as found by Jay \& Willis (1992) and Krauss \& Hoyer (1984) who posit that the more experience with computer technologies will result in the development of more favourable attitudes toward the use of ICT and it is also in line with Poole \& Jackson' Research (1993) that the possession of less computer experience or negative attitudes toward the use of ICT is expected to result in teachers' reluctance to integrate these new technologies in their teaching practices. Of course, negative contents may be reduced by giving an explanation to the students that the use of ICT should bring positive impacts to them to learn and get to know the world better. The students are considered already quite mature and understand to distinguish good and bad things.

\section{Discussion}

The purpose of the use of ICT is to improve the quality of the nation. Rajagukguk \& 
Sihombing (2012) argues that the quality of life of the nation of Indonesia in the future really depends our ability to prepare the young generation and the kids now in the face of a variety of conditions in the future. Utilization of ICT, in addition to being Instruments in the pursuit of also failed at once to increase the quality of education in order to align with other countries. Intensive utilization of ICT in the world resulted in the shifting of competence of human resources. It is parallel to Laabidi's research (2017a) who investigated that students need to acquire the necessary skills to succeed in today's world that is characterized by the widespread use of computer technologies in different fields. Actually, several learners already know how to utilize computers, smart phones, tablets and other devices to look for information or entertain themselves.

The other goal is building the development of science. In this modern era, the growing science fast, including in the field of languages. Development of science in the section of developing is fast in every corner of the world. Through technology, teachers and students know the study of languages and language study topics what is developing in Indonesia including in diverse corners of the world. Do not let the teacher and student, like the frog in the shell doesn't know what is going on out there. Rajagukguk \& Sihombing (2012) explain that no one can resist its ICT development. Its existence has removed the physical boundary lines between countries in terms of the flow of information. No country is able to prevent information from flowing out or out of other countries, because of the limits between countries is not known in the Virtual word of computer. The application of technologies such as LAN, WAN, Internet, Extranet, GlobalNet, the day the more evenly and become culture in society. This finding is also in line with information technology as today's information technology represents only $1 \%$ of the technology anticipated by the end of the year 2050 (Centron \& Davies, 1991), professors are recommended to help learners develop a logical and satisfactory grasp of how to make effective use of various electronic instruments. This is similar to the study conducted by Hite (2005) who affirmed that professors' traditional behaviours must be transformed to help teachers extend their integration of ICT into the curriculum.

The ICT Excellence according to the Rahim (2011) that is ICT has the advantage of providing the information widely, rapidly, and precisely, the ease in learning process of academic, administrative, and financial administration as well as technology support to facilitate in accessing the information above. Application of TIK/ICT also has typical excellence that is not limited by place and time. The government through the Ministry of national education also has responded to the above circumstances and the existence of the information age this by formulating a policy of increased access, efficiency, effectiveness and quality of education as well as management education with implementation of ICT. The use of ICT in language education becomes more prominent as an impact of the rapid changing of educational technology in the field of language teaching. The importance of technology integration in a blended learning environment and how to teach English with technology attracts CALL researchers to do an in-depth investigation in this area (Bradley, 2013; G. \& Hockly, 2007; Jia, 2015; Szecsy, 2015).

The purpose of the use of ICT is quite diverse. One of the important goals of using ICT is keeping track of the days for the skilled use of ICT. Rajagukguk \& Sihombing (2012) argues a lot activity that turns into a very fast. If at the time of first data or information should take days to be processed before it is sent to the other side of the world, currently can be done be done in a 
matter of seconds. The times have changed. If it is not changed, it will be destroyed by the change itself. When a teacher uses ICT, then not only is the teacher who is attempting to use and be skilled in the use of ICT, but also help students develop skills in the use of ICT. Teachers who are not skilled in ICT and not utilizing ICT in learning in class, then it will make himself didn't know about ICT and make students awkward with ICT. Now, ICT is important for everyday life. Especially when the student is graduating, ICT capability will support the work and activities of him/her achieved distinction in later life. In point of fact, the use of ICT in the classroom is very essential for providing chances for learners to function appropriately in an information age. Obviously, with the growth of new technologies, the benefits of computers may have increased step by step as well. It means that undeniably the advantages of ICT contribute and administer so many prospects of taking and handling the higher benefits of advanced technologies.

\section{Conclusion}

Teachers, though very limited, have started to use ICT in learning the English language which includes the use of: multimedia, e-media, e-library, e-learning. ICT is most often used is the multimedia. Not all teachers use online learning with consideration of abuse of the internet to the negative things like opening a site that doesn't rewarding and not worthy to be opened. Teaching English with Technology is still a complex issue among the ESL teachers in Indonesia. For instance, inadequate ICT facilities, troubleshooting support, difficulties in finding appropriate video, video editing skills, and student participation in learning are the factors affecting the use of ICTs in the classroom (Nova, 2017). In plain English, the limited skills of teachers of using ICT, operating internet, obstacles including facilities, bandwidth and others become hindrances of improving their competence using multimedia.

English language teachers of madrasah aliyah in Kalimantan are already acquainted with ICT such as multimedia, e-media, e-library, and e-learning. They use ICT in terms of developing lesson plan, teaching process, and teaching evaluation. The use of ICT should takes into account the availability of facilities and infrastructure, suitability to the curriculum, as well as aspects of the effectiveness and expediency. Strictly speaking, EFL teacher and language educators need a standard and a framework for incorporating ICTs into the teaching and learning horizon.

Some of the constraints in the implementation of ICT in English language learning is computer equipment which is still limited, internet access is limited, not all madrasah aliyah has a language lab, yet no application utilization in gadget, the constraints of age, and accuracy choosing ICT applications. The lack of technology-focused training for the in-service teachers is one of the factors affecting the uptake of ICTs in education. So it is considered to develop their innovation competence in using ICT as it is in with Mansor et al., (2017) who found that innovation in teaching and learning was viewed as a pre requisite in optimizing the output of education.

Moral consideration and advantages the internet is becoming a troubling obstacle for most English language teachers. There is a supposition English language teacher's madrasah aliyah that technology brings negative things. When students are given access to the internet, then there's a snap open the site inappropriate. Strict controls required by the teacher so that the students do not open the site which brings negative content and the teacher needs to give an explanation to them that the use of ICT should bring positive things to learn the English language is faster and easier, as well as consider 
pupils already mature enough to understand and be able to distinguish the good and bad things. This result is conforming to Brand (1998) who has asserted that the students are going to be prepared for a technological society, they must be taught by confident and skilled teachers. This can only be done by adequate training and development of teachers. In other words, the lack of the technological skill could be improved by inviting them to join the development training of using ICT and the teachers' control to remind the students just open the appropriate and necessary website.

\section{References}

Abu-Rmaileh, S., \& Hamdan, K. (2006). Improving student performance using LanSchool broadcast. In Middle-East Teachers of Science, Mathmatics and Computing (METSMac). Abu Dhabi: UEA.

Addison, M. (2011). Students' perceptions of Edmodo and mobile learning and their real barriers towards them. TOJET The Turkish Online Journal of Educational Technology, $14(2)$.

Ahmed, B. (2015). The Implementation of $A$ Flipped Classroom in Foreign Language Teaching. Yildiz Technical University, Turkey.

Al-Kathiri, F. (2014). Beyond the classroom walls Edmodo in Saudi secondary school EFL instruction, attudes and challenges. English Language Teaching, 8(1), 189-202.

Almaktary, H. M. A., \& Al-Kadi, A. M. T. (2017). CALL in Post-Method Era. Indonesian Journal of EFL and Linguistics, 2(2).

Anas, I., \& Musdariah, A. (2018). Being an ETeacher: Preparing the ESL Teacher to Teach English with Technology. JELTL (Journal of English Language Teaching and Linguistics), 3(1).
Annamalai, N. (2017). Exploring Students Use of Facebook in Formal Learning Contexts. Indonesian Journal of EFL and Linguistics, 2(2).

Barker, F. (1994). Integrating computer usage in the classroom curriculum through teacher training. ERIC Document Reproduction Service, (372751).

Batsila, M., Tsihouridis, C., \& Vavougios, D. (2014). Entering the web-2 Edmodo world to support learning.

Becta. (2004). A review of the research literature on barriers to the uptake of ICT by teachers. British Educational Communications and Technology Agency.

Bradley, L. (2013). Language, learning and technology. University of Gothenburg.

Brand, G. (1998). What research says: Training teachers for using technology. Journal of Staff Development, 1(19), 10-13.

Bull, G. (2005). Children, computers,and powerful ideas. Contemparary Issues in Technology and Teacher Education, 5(3/4).

Cahyani, H., \& Cahyono, B. Y. (2012). Teachers' Attitudes and Technology Use in Indonesian EFL Classrooms. TEFLIN Journal, 23(2).

Centron, M. J., \& Davies, O. (1991). Trends shaping the world. The Futurist, 25(50), 1121.

Chouit, D., Nfissi, A., \& Laabidi, H. (2017). Exploring the correlation between professors' use of ICT in teaching and levels of Insitutional support. JELTL(Journal of English Language Teaching and Linguistics), 2(1).

Cowie, N., \& Sakui, K. (2013). It's never too late: An overview of e-learning. ELT Journal, 67(4), 459-467.

Cox, M., Rhodes, V., \& Hall, J. (1988). The use of computer-assisted learning in primary schools: 
Some factors affecting the uptake. In Computers and Education (pp. 173-178).

Davidson, J. (1989). Children and computers together in the early childhood classroom. Albany NY: Delmar Publishers.

Dawes, L. (2001). What stops teachers using new technology. In M. Leask (Ed.), pp. 61-79.

Dyck, H., \& Smither, J. (1994). Age differences in computer anxiety: The role of computer experience, gender, and education. Journal of Educational Computing Research, 10, 239247.

Enriquez, M. A. S. (2014). Students'perceptions on the effectiveness of the use of Edmodo as a supplementary tool for learning. In DSLU Research Congress (pp. 1-6).

Ertmer, P. A. (1999). Addressing First- and SecondOrder Barriers to Change:Strategies for Technology Integration. Educational Technology Research and Development, 4(47), 47-61.

Evenddy, S. S. (2016). Edmodo as media to teach vocabulary. The Journal of English Language Studies, 1(1).

Finley, T. R. (2003). A descriptive study of utilization of technology form a perspective of full-time faculty in Virginia's higher education teacher-education programs (Doctoral dissertation,. The George Washington University.

Dudeney, G., \& Hockly, N. (2007). How to teach English with technology. Educational Technology \& Society, 10 (3), 320-324.

Hite, A. S. (2005). Are we there yet? A study of K-12 teachers' efforts at technology intergration. In ProQuest Dissertations and Theses database.

Hourdequin, M. (2014). Environmental Ethics: From Theory to Practice. London: Bloomsbury.
Hu, Z., \& I, M. (2012). Integrating ICT into college English: An implementation study of a national reform. Education and Information Technologies, 17(92), 147-165.

Husain, C. (2014). Pemanfaatan Teknologi Informasi dan Komunikasi dalam Pembelajaran di SMA Muhammadiyah Tarakan. Jurnal Kebijakan Dan Pengembangan Pendidikan, 2(2), 2014.

Iman, F. N. (2015). Pemanfaatan Teknologi Informasi dan Komunikasi pada Pembelajaran oleh Guru-Guru SMP Negeri 1 Ungaran dalam Rangka Implementasi Kurikulum 2013. Universitas Negeri Semarang.

Insani, H., Nur, Suherdi, D., \& Gustine, G. G. (2018). Undergraduate Students' Perspectives In Using Edmodo As An Educational Social Network. English Review: Journal of English Education, 6(2 June 2018).

Jay, G., \& Willis, S. (1986). The elderly's attitudes towards computers. In A selected Review of the Literature. Chicago: Gerontological Society of America.

Jia, J. (2015). Information and communication technology and language education. In Intelligent Web-Based English Instruction in Middle Schools, 1-28.

Jones, A. (2004). A review of the research literature on barriers to the uptake of ICT by teachers. In British Educational Communications and Technology Agency (Becta).

Kay, R. (1990). Predicting student teacher commitment to the use of computers. Journal of Educational Computing Research, 6, 299309.

Kennah, M. R. (2016). The Use of ICT in the Teaching and Learning Process in Secondary Schools: A Case Study of Two Cameroonian schools. University of Jyväskylä.

Khaloufi, A., \& Laabidi, H. (2017). An Examination of the Impact of Computer Skills on the Effective Use of ICT in the Classroom. 
Indonesian Journal of EFL and Linguistics, $2(1(2017))$.

Krauss, L., \& Hoyer, W. (1984). Technology and the older person: Age, sex, and experience as moderators of attitudes towards computers. New York: Plenum Press.

Kumar, P., \& Kumar, A. (2003). Effects of webbased projects on pre-service and inservice teachers' attitudes towards computers and their technology skills. Journal of Computing in Teacher Education, 19, 87-92.

Kurahman, O. T. (2013). Pengembangan Kompetensi Guru Madrasah dalam Pemanfaatan Teknologi Informasi dan Komunikasi Pada Pembelajaran Agama Islam. In Program Pendidikan Profesi Guru Fakultas Tarbiyah dan Keguruan UIN Sunan Gunung Djati Bandung Tahun 2013.

Laabidi, H. (2017). English Professors' Attitudes towards the Use of ICT in Moroccan Universities. IJEFL: International Journal of EFL, 1(2).

Laabidi, Y., \& Laabidi, H. (2016). A Quantitative Examination of Factors that Influence Technology Integration in Higher Education System. Indonesian Journal of EFL and Linguistics, 1(2 2016).

Larner, D., \& Timberlake L. (1995). Teachers with limited computer knowledge: variables affecting use and hints to increase use. University of Virginia.

Looi, C. Y., \& Yusop, F. D. (2011). Potential use of social networking tool to assist reading comprehension: Implications for practice and future research. Jurnal Pendidikan, 31(91), 116.

Mansor, N. S., Halim, Abdul, H., \& Rahim, Bd, N. (2017). Students' Perspectives towards Innovation of Technology in Teaching and Learning of Language. Indonesian Journal of EFL and Linguistics, 2(2).
Matusevich, M. (1995). School reform: What role can technology play in a constructist setting? Retrieved from: http://delta.cs.vt.edu/edu/fis/ techcons.html

Miles, M. B., \& Huberman, A. M. (1994). Qualitative Data Analysis. California: Sage Publication, Inc.

Mishra, M.P., Tripathy, P., \&Patra, R. (2002). English Communication Skills. College of Engineering and Technology.

Monalisa, \& Ardi, H. (2013). Using 'Edmodo" educational social network in teaching English for high school students. FBS UNP. Padang.

Mustofa, M. A. (2016). Pengelolaan ICT sebagai Media Pembelajaran IPA di SD Negeri 1 Tunggak Kecamatan Toroh Kabupaten Grobogan. Sekolah Pascasarjana Universitas Muhammadiyah Surakarta.

Nickell, G., \& Pinto, J. (1986). Computer attitudes scale. Computers in Human Behaviour, 2, 301-306.

Nova, M. (2017). Utilizing video for technology integration support in Indonesian EFL classroom: usages and obstacles. Indonesian Journal of EFL and Linguistics, 2(1), 15-28.

Parkisnon, J., \& Hollamby, P. (2003). PowerPoin: Just another slide show or a useful learnin aid? School Science Review, 48(309), 61-68.

Poole, M., \& M, J. (1993). Communication theory and group suppport systems. New Perspectives, 281-293.

Potosky, M, D., \& Bobko, P. (1998). The computer understanding and experi ce scale: A selfreport measure of computer experience. Computers in Human Behaviour, 14(2), 337348.

Pulungan, S. (2017). Pemanfaatan ICT falam Pembelajaran PAI. QUERY. Jurnal Sistem Informasi, 1(1). 
Purnawan, P., Sundayana, W., \& Susilawati. (2016). The use of edmodo in teaching writing in a blended learning setting. Indonesian Journal of Applied Linguistics, 5(2), 242-252.

Puspitaloka, N., Rachmawati, I., \& Sonjaya, O. D. (2018). Edmodo as Educational Social Network in Teaching Course Design of EYL. Script Journal (Journal of Linguistic and English Teaching), 3(2).

Rahim, M. Y. (2011). Pemanfaatan ICT sebagai media pembelajaran dan informasi pada UIN Alauddin Makassar. Sulesana, 6(2).

Rajagukguk, J., \& Sihombing, P. (2012). Optimalisasi Pemanfaatan Teknologi Informasi dan Komunikasi (ICT) Sebagai Peluang di Era Globalisasi Ekonomi. Prosiding Seminar Teknologi Informasi. STMIK IBBI MEDAN.

Raman, A., \& Mohamed, A. . (2013). Issues of ICT usage among Malaysian secondary school English taechers. English Language Teaching, 6(9), 74-82.

Rathnasena, et al. (2013). How ICT can be Used Effectively to Enhance English Language Learning In Tertiary Education: A Study Focusing on Speaking and Listening Skills. In SAITM Research Symposium on Engineering Advancements 2013.

Rogers, P. L. (2000). Barriers to adopting emerging technologies in education. Journal of Educational Computing Research, 22(4), 455-472.

Roig-Vila, R., \& Mengual-Andrés, S. (n.d.). New Literacy for Reading Using ICT. ECPS Journal, 10.
Roweliffe, S. (2003). Using PowerPoint effectively in science education: Lessons from research and guidance for the classroom. School Science Review, 84(309), 69-75.

Styati, E. W. (2016). Effect of YouTube Videos and Pictures on EFL Students' Writing Performance. Dinamika Ilmu, 16(2).

Sudibyo, L. (2011). Peranan dan Dampak Teknologi Informasi dalam Dunia Pendidikan di Indonesia, WIDYATAMA, 20(2), 2011.

Suhirman. (2015). Pemanfaatan Teknologi Multimedia Dalam Pembelajaran Pendidikan Agama Islam. MADANIA, 19(2).

Szecsy, C. E. (2015). Technology in language teaching and learning. In J.M.Gonzales (Ed.).Encyclopedia of Bilingual Education. Thousand Oaks: SAGE Publications.

Tanveer, M. (2011). Integrating E-learning in classroom-based language teaching: Perceptions, challenges, and strategies. In 4th International Conference "ICT for Language Learning (pp. 1-6).

Trimmel, M., \& Bachman, J. (2004). Cognitive, social, motivational adn health aspects of students in laptop classroom. Journal of Technology and Teacher Education, 14(1), 173-207. 